\title{
Phytoplankton scenario and microcystin in water during extreme drought in semiarid tropical water supplies, Northeastern Brazil
}

\author{
A. H. G. Rego ${ }^{a}$ (D), A. Rangel-Junior ${ }^{b}$ (D) and I. A. S. Costa ${ }^{a *}$ (D) \\ ${ }^{a}$ Grupo de Pesquisas em Ecologia e Microbiologia de Ecossistemas Aquáticos, \\ Programa de Pós-graduação em Desenvolvimento e Meio Ambiente - PRODEMA, \\ Departamento de Microbiologia e Parasitologia, Centro de Biociências, Universidade Federal do Rio Grande do Norte - \\ UFRN, Campus Universitário, BR 101, Lagoa Nova, CEP 59072-000, Natal, RN, Brasil

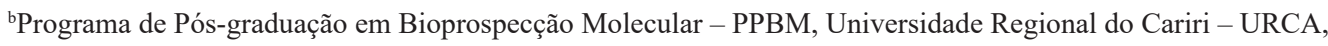 \\ Rua Cel. Antônio Luiz, 1161, Pimenta, CEP 63105-000, Crato, CE, Brasil \\ *e-mail: iasoaresc@gmail.com
}

Received: July 11, 2017 - Accepted: April 5, 2018 - Distributed: February 28, 2020

(With 6 figures)

\begin{abstract}
The objective of this study was to characterize the limnological, microystin and phytoplankton community of five tropical eutrophic reservoirs located in the Brazilian northeastern semi-arid region, used for domestic use at the time of extreme drought and reduction of water volume. The study was conducted in July and August 2015, and an integrated sample of the water column was collected at three points near the dam in each reservoir. Analysis of limnological parameters, identification and quantification of phytoplankton, with emphasis on cyanobacteria were performed, as well as detection of microcystin by means of immunoassay (ELISA). The reservoirs presented $\sim 90 \%$ water volume reduction. High turbidity and concentrations of nitrogen and phosphorus, as well as high cyanobacterial densities, revealed an increase in the eutrophic state for hypereutrophy. The total biovolume of phytoplankton and cyanobacterial density is high, plus an average increase in relation to previous studies of $350 \%$ and $150 \%$, respectively. The density of cyanobacteria and microcystin concentration presented values above acceptable levels for drinking water according to Brazilian legislation. A phytoplankton community was represented by 17 functional groups, including potentially toxic cyanobacteria species such as Planktothrix agardhii (S1), Microcystis aeruginosa $(\mathbf{M})$, Anabaena planktonica e Anabaena spp. (H1), Cylindrospermopsis raciborskii (Sn). Our results confirm that conditions of extreme drought and reduction of the volume of the reservoirs influence the composition, biovolume of phytoplankton and water quality, but not the increase of total microcystin in the analysed, although above $1 \mu \mathrm{g}^{-1}$ registered a significant decrease of water quality in used for human consumption.
\end{abstract}

Keywords: cyanobacteria, functional groups, reservoirs, heavy metals, eutrofication.

\section{Cenário de fitoplanctônico e microcistinas na água durante extrema estiagem em reservatórios tropical semiárido de abastecimento de água, nordeste do Brasil}

\section{Resumo}

O objetivo deste trabalho foi caracterizar a comunidade limnológica, microistalina e fitoplanctônica de cinco reservatórios eutróficos tropicais localizados no semi-árido nordestino brasileiro, utilizados para uso doméstico no período de seca extrema e redução do volume de água. O estudo foi realizado em julho e agosto de 2015, e uma amostra integrada da coluna de água foi coletada em três pontos próximos à barragem em cada reservatório. Análises de parâmetros limnológicos, identificação e quantificação do fitoplâncton, com ênfase em cianobactérias, foram realizadas, assim como a detecção de microcistina por meio de imunoensaio (ELISA). Os reservatórios apresentaram $\sim 90 \%$ de redução do volume de água. A alta turbidez e as concentrações de nitrogênio e fósforo, bem como as altas densidades de cianobactérias, revelaram um aumento no estado eutrófico da hipereutrofia. O biovolume total de fitoplâncton e densidade de cianobactérias é alto, além de um aumento médio em relação a estudos anteriores de $350 \%$ e $150 \%$, respectivamente. A densidade de cianobactérias e a concentração de microcistina apresentaram valores acima dos níveis aceitáveis para água de consumo, de acordo com a legislação brasileira. Uma comunidade fitoplanctônica foi representada por 17 grupos funcionais, incluindo espécies de cianobactérias potencialmente tóxicas, como Planktothrix agardhii (S1), Microcystis aeruginosa (M), Anabaena planktonica e Anabaena spp. (H1), Cylindrospermopsis raciborskii (Sn). Nossos resultados confirmam 
que condições de seca extrema e redução do volume dos reservatórios influenciam a composição, o biovolume de fitoplâncton e a qualidade da água, mas não o aumento do total de microcistina no analisado, embora acima de $1 \mu \mathrm{g}^{-1}$ tenha registrado uma diminuição significativa da qualidade da água usado para consumo humano.

Palavras-chave: cianobactérias, grupos funcionais, reservatório, metais pesados, eutrofização.

\section{Introduction}

The Brazilian semi-arid region is characterized by a peculiar hydrological regime, prolonged droughts, alternated by short periods of rain, with low annual volume $(\sim 400 \mathrm{~mm})$, high irradiation and evaporation rate, long residence time (Arfi, 2003; Burford and O'Donohue, 2006; Romo et al., 2013). Studies on the ecology of shallow tropical lakes in the semi-arid region have clearly shown that such climatic conditions favor the increase of turbidity, nutrient concentration and increase of algal biomass, which associated with anthropic pollution causes a decrease in water quality (Naselli-Flores, 2003) and the establishment of a permanent scenario of eutrophication in reservoirs, which may promote a dominance of bloom-forming potentially toxic cyanobacteria (Chorus and Bartram, 1999; Romo et al., 2013). Periods of seasonal drought (predictable in terms of time and duration), or supra-seasonal (not predictable as to their duration and time), require different responses from the biota of an aquatic ecosystem. In the first case, the biotic beings present adaptations to seasonal drought conditions, whereas in the second situation the biota finds difficulties of adaptation and overcoming this extreme condition (Lake, 2003; Romo et al., 2013).

The description and analysis of the limnological scenario, as well as the availability of phytoplankton nutrients, such as phosphorus and nitrogen, and attributes contribute to a better environmental ecological diagnosis of the ecosystem, besides identifying the conditions that determine water quality (Pinto and Becker, 2014). From this knowledge it is possible to draw a profile of an optimal environment for the blooms in an aquatic environment.

The phytoplankton community becomes a worrying biological variable due to the excessive growth caused by the phenomenon of eutrophication, which is a factor of loss of water quality in reservoirs, as is the case in the Brazilian Northeast (Eskinazi-Sant'Anna et al., 2006; Costa et al., 2006a, b, 2009; Vasconcelos et al., 2011). It is known that this phenomenon causes a number of negative impacts on the dynamics of aquatic ecosystems, for example, toxic blooms of cyanobacteria, that constitute the main responsible for this blooming because they present several ecological advantages over other phytoplankton groups (Chorus and Bartram, 1999). Several species of cyanobacteria indicate a potentially toxic risk to aquatic and terrestrial organisms, including human health (Van Apeldoorn et al., 2007).

Studies on the dynamics of phytoplankton in tropical regions (Calijuri et al., 2002; Crossetti and Bicudo, 2008; Soares, 2009; Soares et al., 2012; Fonseca and Bicudo, 2008), especially in the northeastern Brazilian semi-arid region (Huszar et al., 2000; Bouvy et al., 2000; Bittencourt-Oliveira et al., 2010; Bouvy et al., 2003; Dantas et al., 2011, 2012; Barbosa et al., 2012; Costa et al., 2009), report relationships among local climatic conditions and eutrophication on favoring the dominance of cyanobacteria and decreasing water quality. Further evidence of the influence of the hydrological regime of semi-arid region on the composition and dominance of cyanobacteria is shown by Medeiros et al. (2015), Braga et al. (2015) and Costa et al. (2016). Other phytoplankton studies carried out in eutrophic reservoirs in the Brazilian Northeast, reveal the occurrence of potentially toxic species bloom-forming such as Cylindrospermopsis raciborskii, Microcystis aeruginosa and Planktothrix agardhii (Medeiros et al., 2015; Costa et al., 2006a, b, 2009) and the presence of their toxins (microcystins and saxitoxins) in these environments is reported by Fonseca et al. (2015) and Costa et al. (2006a). Such studies are important because they contribute to establish conditions and make predictions of future scenarios of the phytoplankton behavior in regions affected drastically by prolonged droughts, contributing to the management of water for the population. Functional attributes allow greater generalization, where each group corresponds to species that relate to certain ecosystem functions, because grouping them is based on morphological, physiological and ecological equivalences (Reynolds et al., 2002). In this way, a study will be adopted as a classification parameter to complement the phylogenetic approach.

In this study we want to design the scenario of the limnological conditions and the phytoplankton community of five eutrophic tropical reservoirs of the Brazilian northeastern semiarid used for domestic supply in an instant of extreme reduction of water level caused by a severe dry season. We aimed to analyze the changes in composition, biomass and functional groups of phytoplankton, with emphasis on blooming cyanobacteria, and the presence and degree of toxicity of microcystin in an instant of drastic reduction of volume of water caused by severe and prolonged drought. It is expected to find a marked increase in cyanobacterial biomass and microcystin levels, associated with decreased water quality, in comparison with other studies.

\section{Material and Methods}

\subsection{Study area}

The study was conducted in five reservoirs, all located in the Brazilian semi-arid region and intensely submitted to periodic droughts, being located in the Piancó-Piranhas-Açu Hydrographic Basin (Figure 1). The Barragem Armando Ribeiro Gonçalves - ARG ( $\left.5^{\circ} 40^{\prime} 21.4^{\prime \prime} \mathrm{S} 36^{\circ} 53^{\prime} 05.0^{\prime \prime} \mathrm{W}\right)$; Boqueirão-BQ (6 $6^{\circ} 41^{\prime} 43.0^{\prime \prime}$ ' $\left.36^{\circ} 37^{\prime} 44.4^{\prime \prime} \mathrm{W}\right)$, Gargalheiras - GAR ( $\left.6^{\circ} 25^{\prime} 30.8^{\prime \prime} \mathrm{S} 36^{\circ} 36^{\prime} 08.2^{\prime \prime} \mathrm{W}\right)$, Açude Itans IT (6 $\left.6^{\circ} 29^{\prime} 26.6^{\prime \prime} \mathrm{S} 37^{\circ} 03^{\prime} 57.1^{\prime \prime} \mathrm{W}\right)$ and Passagem das 


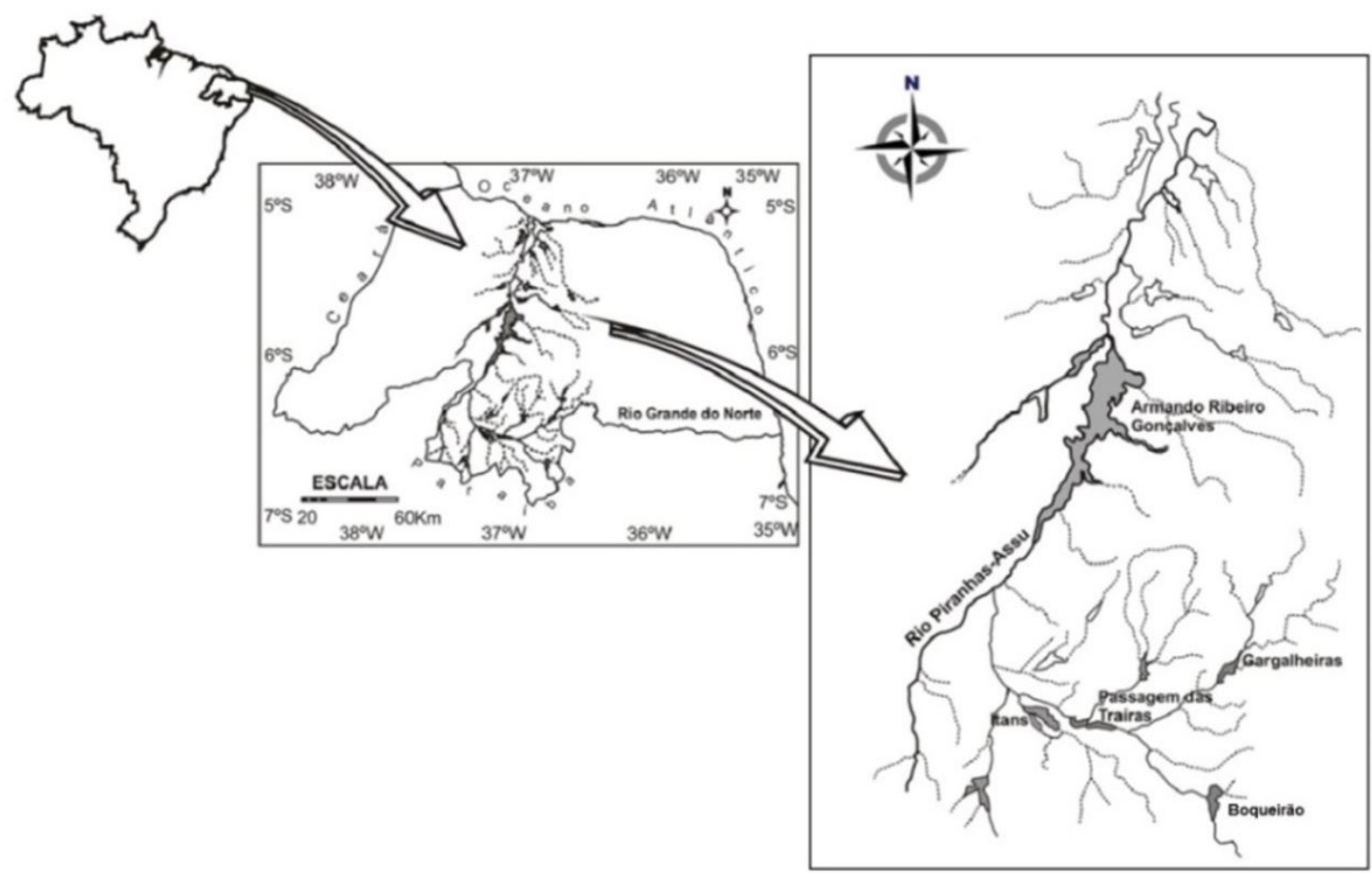

Figure 1. Location and area of study. Barragem Armando Ribeiro Gonçalves; Gargalheiras; Açude Itans; Passagem das Traíras; Açude Boqueirão. (Rio Grande do Norte, Northeast Brazil) Costa et al. (2009).

Traíras - PT (6 30'52.5” S 36 56’32.9” W). IT, BQ, PT and GAR are medium-sized reservoirs, whereas ARG is large in size, although in the sample period all were presented as small and shallow operating below dead volume, except for ARG. All of them are used for domestic and industrial supplies and recreational activities, fish farming and fruit irrigation. As a consequence, they are impacted by intense diffuse loads of nutrients, resulting from multiple-use wastes, intense bare soil erosion, and urban and agricultural runoff, resulting in alternation of eutrophic to hypereutrophic periods (Costa et al., 2009).

\subsection{Limnetical sampling and analysis}

The samples were collected in July and August 2015 at the height of a severe prolonged and progressive drought for the last five years, where the reservoirs were with levels of water well below the dead volume. Three of them (GAR, IT and PT) presented less than $1 \%$ of their volumetric capacity, while $\mathrm{ARG}$ and BQ with $20 \%$ or less. Water samples were obtained with a bottle of Van Dorn in the limnetic and central region (near the dam) at three equidistant points. At each point of the limnetic region of the reservoirs with depths greater than 3 meters (ARG and BOQ), sub samples of 5 liters were collected at each depth of the water column (subsurface, middle and bottom) and integrated in a bucket, totaling 15 liters. Later, in the same way, the samples of the water column of each point of the limnetic region were again integrated, totaling 45 liters, in which it was used for analyzes of nutrients, metals, phytoplankton and microcystins. In the IT and PT reservoirs with depth of approximately $3 \mathrm{~m}$, samples were integrated only from the subsurface and bottom of the column, totaling 30 liters. In the GAR reservoir, which had depth of approximately 1 meter, the integrated sample was obtained from three subsurface points, totaling 15 liters. Data from the monthly precipitation in the five environments were obtained by the Rio Grande do Norte Agricultural Research and Development Company (EMPARN, 2016). Monthly precipitation data from the last five years, including the period of this study, were considered.

In each reservoir the water transparency was estimated by the depth measurement of the Secchi disk. Vertical profiles of turbidity, temperature, hydrogen ionic potential $(\mathrm{pH})$, dissolved oxygen and conductivity were obtained through the Horiba multiparameter probe. The concentrations of nitrogen and total phosphorus in the water were estimated by spectrophotometry according to the recommendations of APHA (2000). The determination of the total phosphorus was done by the Ascorbic Acid Method after digestion of the samples in potassium persulfate and the total nitrogen by the oxidation of the nitrogenous compounds to nitrate, according to Valderrama (1981). Concentrations of heavy metals (Arsenic, Barium, Cadmium, Lead, Copper, Chromium, Mercury and Nickel) were detected in the water and sediment by internal procedure PLIE01R00, according to Official USEPA 6010 standard, carried out at the Primary Processing and Reused Water Reactor and Residue (NUPPRAR) of the Federal University of Rio Grande do Norte (UFRN). 


\subsection{Phytoplankton sampling, analysis and microcystin}

Samples for identification of phytoplankton species were collected in vertical and horizontal trawls with plankton net $(20 \mu \mathrm{m})$ and fixed with $4 \%$ formalin. The taxonomic identification of Cyanobacteria was made using the Komárek System (Komárek and Anagnostidis 2000, 2005; Komárek and Jankovská, 2001); Round (1971) for Chlorophyceae and Simonsen (1979) for Diatoms.

For the quantification of phytoplankton, water samples integrated in the water column $(250 \mathrm{~mL})$ were preserved with acetic acid and quantified under inverted microscopy, following the method of Ütermohl (1958) and counting the individuals through random fields. The error less than $20 \%$, at a $95 \%$ confidence level according to the criterion of Lund et al. (1958). The number of fields varied between the samples and the conclusion of the count was performed taking as a criterion the count of at least 100 individuals of a dominant species. For samples with apparent blooms we used the criterion of 400 for a $10 \%$ environment error (Chorus and Bartram, 1999). The biovolume was obtained by geometric approximation, multiplying the density of each species by the average volume of its cells, considering, when possible, the average size of 30 individual samples of each species (Hillebrand et al., 1999). Phytoplankton functional groups were defined according to Reynolds et al. (2002) and Pádisak et al. (2009) from the species that contributed with at least $5 \%$ of the relative biovolume in at least one sample, being considered dominant.

For analysis of total microcystin (particulate and dissolved), integrated samples of water in the water column are obtained in each reservoir. The extraction was done by ice-defrost (three times), followed by the sonication process of the sample for disruption of cells and filtration through Whatman GF / C, glass fiber filters. Microcystin total detection was performed using the Enzyme Linked Immunoadsorbent Assay (ELISA), using a Microcystin Plate Kit ELISA (ENVIROLOGIX INC.) and microplate reader. Descriptive statistics were applied to the data by means of calculating the mean aritimética as measure of central tendency and of the standard deviation and frequency of occurrence of the species (\%) (Matteucci and Colma, 1982).

\section{Results}

\subsection{Limnological scenario}

The levels of precipitation and volume of the reservoirs in the sample period were extremely low as a consequence of severe drought in the last five years. Rainfall in the year 2015 in the five reservoirs ranged from $261 \mathrm{~mm}$ (BQ) to $449 \mathrm{~mm}$ (ARG), where all dams were below average annual precipitation in that year (Figure 2). GAR, IT and PT presented only $0.05 \%, 0.69 \%$ and $0.52 \%$ of the volumetric capacity, respectively, denoting an operating character below the dead volume. While ARG presented a volume of $26.8 \%$ and BOQ, $11.5 \%$ (Table 1 ).

Transparency in IT and PT was below $0.5 \mathrm{~m}$, indicating high turbidity, while BQ and ARG exceeded the mark above. The euphotic zone (Zeu) was lower in PT $(0.7 \mathrm{~m})$ and IT (0.6) and reached a maximum depth of $1.83 \mathrm{~m}$ in ARG. The percentage of light in the euphotic zone was lower than 20\% in ARG and PT, reaching 26\% in BQ and $28 \%$ in IT (Table 1). The dissolved oxygen profile showed a clinograde-positive pattern, presenting low concentrations ranging from 2.5 to $5.5 \mathrm{mg} . \mathrm{L}^{-1}$ up to 15 meters deep, decreasing to concentrations below $1 \mathrm{mg} . \mathrm{L}^{-1}$ in the hypolimonium.

Thermal microstratification were recorded in the reservoirs in IT and PT, showing a variation of $29.8^{\circ} \mathrm{C}$ in the surface to $25^{\circ} \mathrm{C}$ in the bottom. ARG and BQ showed a homogeneous temperature profile ranging from $24{ }^{\circ} \mathrm{C}$ on the surface to $23.5^{\circ} \mathrm{C}$ at the bottom (Figure 2). The water column presented clinigrade-positive oxygen profiles with oxygen deficiency at the bottom from $1 \mathrm{~m}$ depth of the IT and PT reservoirs (1 mg.L-1). Oxicline from $2 \mathrm{~m}$ depth occurred in ARG and BQ (Figure 3). Surface dissolved oxygen concentrations ranged from $9.9 \mathrm{mg} . \mathrm{L}^{-1}$ in $\mathrm{ARG}$; $9.6 \mathrm{mg} . \mathrm{L}^{-1}$ in BQ to $7.4 \mathrm{mg} . \mathrm{L}^{-1}$ (IT); $4.2 \mathrm{mg} . \mathrm{L}^{-1}$ (PT); and $5.1 \mathrm{mg} . \mathrm{L}^{-1}$ (GAR). At the bottom they were very low in IT (1.1 mg.L $\left.{ }^{-1}\right)$, PT (1.2 mg.L.- ${ }^{-1}$ ) (Figure 3).

The total nitrogen levels were minimum of $763 \mu \mathrm{g} . \mathrm{L}^{-1}$ in BQ and maximum of $29059 \mu \mathrm{g} . \mathrm{L}^{-1}$ in IT (Table 1). Taking

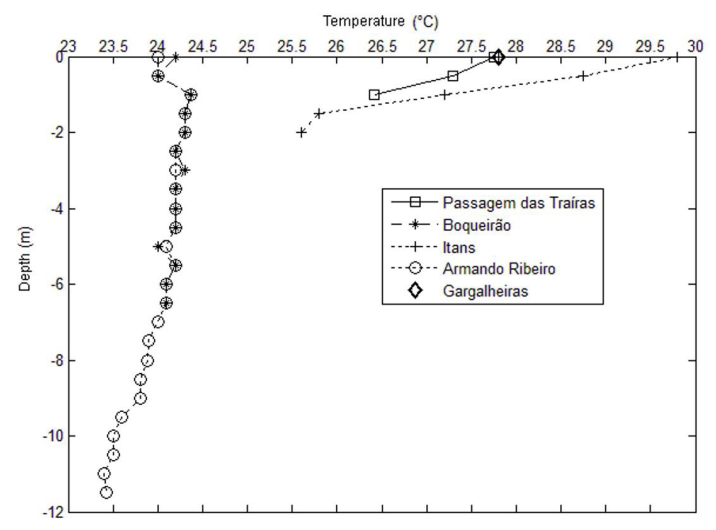

Figure 2. Vertical Temperature Profile.

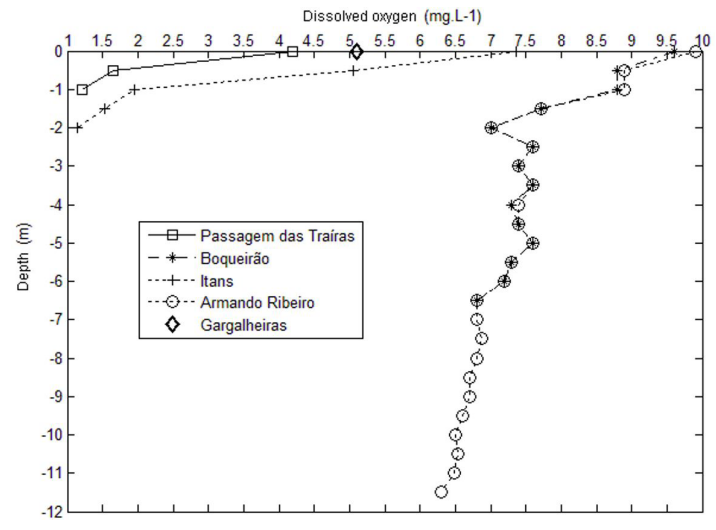

Figure 3. Vertical profile of dissolved oxygen. 
Table 1. Hydrological, morphometric characteristics, Physical-chemical values, microcystin, heavy metals, phytoplanktonbiovolume increase ratio and cyanobacteria (from previous studies) and other parameters of the five reservoirs.

\begin{tabular}{|c|c|c|c|c|c|}
\hline Reservoirs Variables & ARG & BQ & GAR & IT & PT \\
\hline Vol max $\left(\mathrm{m}^{3}\right)$ & $2,400,000,000.00$ & $84,792,119.23$ & $44,421,480.38$ & $81,750,000.00$ & $49,702,393.65$ \\
\hline Vol med $\left(\mathrm{m}^{3}\right)$ & $643,210,000.00$ & $9,813,192.01$ & $241,726.9$ & $568,000.00$ & $261,297.00$ \\
\hline VMA 2015 (\%) & 26.8 & 11.5 & 0.05 & 0.69 & 0.52 \\
\hline $\mathrm{Zmax}(\mathrm{m})$ & 40 & 29 & 25 & 23 & 25 \\
\hline Zmed (m) & 11.1 & 4.4 & 4.3 & 5.1 & 3.9 \\
\hline Zmax $2015(\mathrm{~m})$ & 13.5 & 7.3 & - & 2.6 & 3.5 \\
\hline TR (years) & 2.82 & 6.22 & 1.01 & 2.46 & 0.26 \\
\hline Transparency (m) & 0.61 & 0.65 & - & 0.25 & 0.21 \\
\hline Euphotic zone (\%) & 19 & 28 & - & 26 & 18 \\
\hline Cond. $\left(\mu \mathrm{S} . \mathrm{cm}^{-1}\right)$ & 1.67 & 1.45 & - & 1.21 & 1.35 \\
\hline $\begin{array}{l}\mathrm{pH} \text { (average) } \\
\text { (Average depth; min-max) }\end{array}$ & $8(7-9)$ & $7.9(7.8-8)$ & & $8.1(7.9-8.6)$ & $8.2(7.8-8.5)$ \\
\hline $\mathrm{TP}\left(\mu \mathrm{g} \cdot \mathrm{L}^{-1}\right)$ & 56.5 & 52.9 & 901.4 & 203.8 & 413.2 \\
\hline $\mathrm{TN}\left(\mu \mathrm{g} \cdot \mathrm{L}^{-1}\right)$ & 900 & 763 & 4273 & 29059 & 1955 \\
\hline $\mathrm{PO}_{43-}\left(\mu \mathrm{g} \cdot \mathrm{L}^{-1}\right)$ & 18.9 & 16.4 & 457.5 & 57.6 & 63.2 \\
\hline $\mathrm{NH}_{3}\left(\mu \mathrm{g} \cdot \mathrm{L}^{-1}\right)$ & 62.5 & -25 & 228.9 & 99.8 & 11.2 \\
\hline Ba sed $\left(\mathrm{mg} \cdot \mathrm{Kg}^{-1}\right)$ & 565.8 & 750.2 & 685.5 & 1372.2 & 836.6 \\
\hline Ni sed $\left(\mathrm{mg} \cdot \mathrm{Kg}^{-1}\right)$ & 71.3 & 82.8 & 74.3 & 155.6 & 115.8 \\
\hline Cr sed $\left(\mathrm{mg} \cdot \mathrm{Kg}^{-1}\right)$ & 88.4 & 117.9 & 94.4 & 210.3 & 147.1 \\
\hline Ba water $\left(\mathrm{mg} \cdot \mathrm{L}^{-1}\right)$ & 0.11 & 0.95 & 0.58 & 0.3 & 0.8 \\
\hline $\operatorname{MICY}\left(\mu g . L^{-1}\right)$ & 3.3 & 3.1 & 3.3 & 3.2 & 3.4 \\
\hline $\begin{array}{l}\text { Phyto Biov. and Cyano } \\
\text { dens. increase ratio (\%) }\end{array}$ & $437 / 286$ & $543 / 63$ & $530 / 274$ & $90 / 80$ & $89 / 471$ \\
\hline
\end{tabular}

ARG = Armando Ribeiro Gonçalves; $\mathrm{BQ}=$ Boqueirão; GAR = Gargalheiras; $\mathrm{IT}=$ Itans; PT $=$ Passagem das Traíras; Vol $\max =$ Max volume; Vol med = Average volume; VMA $2015=$ Average volume during collection; Zmax = Depth Maximum depth $\mathrm{Zm}=$ mean depth; Zmax 2015 = Mean depth during collection; TR = Time of residence; $\mathrm{TP}=$ Total phosphorus; Cond. = Electric conductivity; $\mathrm{PO}_{43}$ = Phosphate; $\mathrm{NH}_{3}=$ Ammonia; $\mathrm{TN}=$ Total Nitrogen; $\mathrm{Ba}=\mathrm{Barium} ; \mathrm{Ni}=\mathrm{Nickel}$; $\mathrm{Cr}=$ Chromium; Sed = sediment; MICY = Microcystin; Phyto. Biov. = Phytoplankton biovolume; Cyano. Dens. $=$ Cyanobacteria density). Source: EMPARN (2016).

into account the total phosphorus amounts, which were used to characterize eutrophic environments in semi-arid zones, values of phosphorus concentrations higher than $100 \mu \mathrm{g} . \mathrm{L}^{-1}$ were obtained in three reservoirs (GAR, IT, PT) according to Table 1. Reservoirs operating below the dead volume, GAR, IT and PT, presented very high total phosphorus amounts: $901.44 \mu \mathrm{g} . \mathrm{L}^{-1}, 203.88 \mu \mathrm{g} . \mathrm{L}^{-1}$ and $413.29 \mu \mathrm{g} . \mathrm{L}^{-1}$, respectively. The $\mathrm{pH}$ in all the reservoirs ranged from 7 to 9 , thus showing to be neutral-alkaline. The electrical conductivity was $1.67 \mu \mathrm{S} . \mathrm{cm}^{-1}$ (ARG); $1.45 \mu \mathrm{S} . \mathrm{cm}^{-1}$ (BQ); $1.21 \mu \mathrm{S} . \mathrm{cm}^{-1}$ (IT); and $1.35 \mu \mathrm{S} . \mathrm{cm}^{-1}(\mathrm{PT})$.

The analysis of heavy metals in the sediment revealed the presence of Barium, Chromium and Nickel while in the water only Barium was detected, whose concentration in the sediment of the reservoirs ranged from $565 \mathrm{mg} . \mathrm{Kg}^{-1}$ (ARG) to $1372 \mathrm{mg} \cdot \mathrm{Kg}^{-1}$ (IT). The change in nickel concentrations was $71 \mathrm{mg} \cdot \mathrm{Kg}^{-1}$ (ARG) at $155 \mathrm{mg} \cdot \mathrm{Kg}^{-1}$ (IT). Chromium showed values of $88 \mathrm{mg} . \mathrm{Kg}^{-1}$ (ARG) at $210 \mathrm{mg} \cdot \mathrm{Kg}^{-1}$ (IT). The concentration of Barium in the water presented values of $0.32 \mathrm{mg} . \mathrm{L}^{-1}(\mathrm{IT}) ; 0.95 \mathrm{mg} \cdot \mathrm{L}^{-1}(\mathrm{BQ}) ; 0.11 \mathrm{mg} \cdot \mathrm{L}^{-1}$ (ARG); $0.58 \mathrm{mg} . \mathrm{L}^{-1}$ (GAR); $0.81 \mathrm{mg} . \mathrm{L}^{-1}$ (PT) (Table 1).

\subsection{Phytoplankton scenario and microcystin}

The phytoplankton community was represented by 17 functional groups according to Reynolds et al. (2002) and Padisák et al. (2009): C, D, MP, W1, S1, F, B, K, J, Lo, H1, P, W2, Z, Sn, X1 and M. Five taxonomic classes of phytoplankton (Cyanobacteria, Cryptophyceae, Chlorophyceae, Bacillariophyceae and Euglenophyceae), totaling 45 taxa were found in the five reservoirs. The total biovolume of the phytoplankton for the five environments was $166.47 \mathrm{~mm}^{3} \cdot \mathrm{L}^{-1}$ (ARG); $38.22 \mathrm{~mm}^{3} \cdot \mathrm{L}^{-1}(\mathrm{BQ}) ; 344.18 \mathrm{~mm}^{3} .^{\mathrm{L}-1}$ (GAR); $69.53 \mathrm{~mm}^{3}$. $\mathrm{L}^{-1}$ (IT) and $85.58 \mathrm{~mm}^{3}$. $\mathrm{L}^{-1}$. Cyanobacteria represented $90 \%$ of the total phytoplankton biomass in GAR and BQ, and 99\% in ARG, IT and PT. The second group with the highest biomass of phytoplankton in all environments was the chlorophyceae, corresponding to $11 \%$ of the total phytoplankton biomass, $8 \%$ in GAR and BQ (Figure 4). The other groups represent $1 \%$ or less.

A total of 22 taxa of cyanobacteria were identified, of which the potentially toxic ones stand out, being 7 of the group Nostocales, 5 Oscillatoriales and 9 Chroococcales. Potentially toxic cyanobacteria comprised $45 \%$ 
occurring from $60 \%$ to $75 \%$ in the five reservoirs, being represented by the Anabaena planctonica; Anabaena spp.; Aphanocapsa delicatissima; Aphanocapsa holsatica; Cylindrospermopsis raciborskii; Microcystis aeruginosa; Planktothrix agardhii and P. isothrix presented 100\% occurrence. The reservoir with the highest diversity of cyanobacteria was BQ $(n=12)$, followed by ARG $(n=11)$, while PT presented lower diversity $(n=6)$. GAR and IT presented 7 species each. The most representative functional group was $\mathbf{S 1}$ (31\%), followed by $\mathbf{H 1}$ and $\mathbf{K}$, both with 14\%, and $\mathbf{L o}$ and $\mathbf{M}$, both with $10 \%$. The highest total biomass of cyanobacteria was GAR with $303.89 \mathrm{~mm}^{3}$. $\mathrm{L}^{-1}$. The others presented biomass of $164.32 \mathrm{~mm}^{3} \cdot \mathrm{L}^{-1}$ (ARG), $29.9 \mathrm{~mm}^{3} \cdot \mathrm{L}^{-1}$ (BQ), $69.14 \mathrm{~mm}^{3}$. $\mathrm{L}^{-1}$ (IT), $84.81 \mathrm{~mm}^{3}$. $\mathrm{L}^{-1}$ (PT). In ARG the species Planktothrix agardhii represented $84 \%$ of the biovolume of cyanobacteria, followed by Anabaena planctonica (5\%), Sphaerocavum brasiliense (5\%) and P. isothrix (5\%). In BQ the dominant species was Sphaerocavum brasiliense (52\%), followed by Planktolyngbya sp. (28.1\%) and Anabaena planctonica (10\%). GAR had the most representative species Sphaerocavum brasiliense (77\%) and Microcystis aeruginosa (12.2\%). IT showed prevalence in Anabaena sp (89.8\%). PT had as predominant species

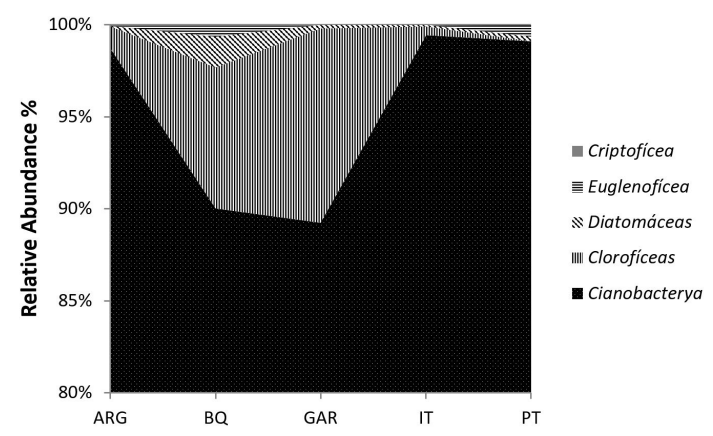

Figure 4. Relative abundance of phytoplanktonic groups (biovolume in $\mathrm{mm}^{3} \cdot \mathrm{L}^{-1}$ ) in July and August 2015. $\mathrm{ARG}=$ Armando Ribeiro Gonçalves; $\mathrm{BQ}=$ Boqueirão; $\mathrm{GAR}=$ Gargalheiras; $\mathrm{IT}=$ Itans $; \mathrm{PT}=$ Passagem das Traíras .

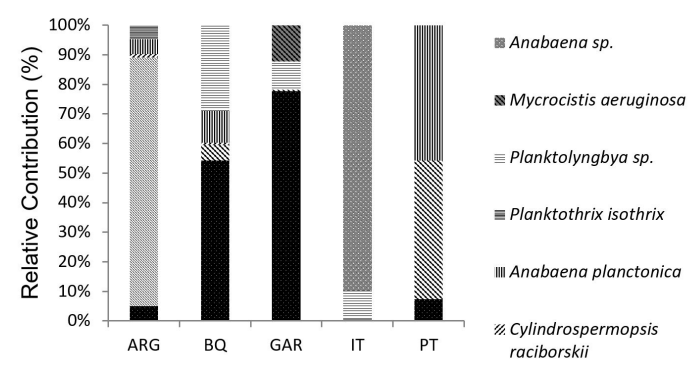

Figure 5. Relative contribution of cyanobacteria (\%) in July and August 2015. ARG = Armando Ribeiro Gonçalves; $\mathrm{BQ}=$ Boqueirão; GAR = Gargalheiras; IT = Itans; $\mathrm{PT}=$ Passagem das Traíras.
Cylindrospermopsis raciborskii (45\%) and Anabaena planctonica (44\%) as indicated in Figure 5.

The functional group S1 presented biovolume of $145.77 \mathrm{~mm}^{3}$. $\mathrm{L}^{-1}$ in ARG and was represented by the species Planktothrix agardhii that presented a relative contribution of $87 \%$. BQ had group $\mathbf{M}$ as the most abundant with biovolume of $15.56 \mathrm{~mm}^{3} . \mathrm{L}^{-1}$, represented here by the cyanobacteria species Sphaerocavum brasiliense. In GAR, the $\mathbf{M}$ group also stood out due to the large number of biovolume representatives $\left(272.49 \mathrm{~mm}^{3} . \mathrm{L}^{-1}\right)$ of the cyanobacteria $S$. brasiliense and Microcystis aeruginosa. IT appears with group $\mathbf{H 1}$ as more representative, being its biovolume of $62.13 \mathrm{~mm}^{3}$.L-1 and the cyanobacteria of the genus Anabaena, mainly Anabaena planktonica were the most abundant. PT reservoir was highly representative for the $\mathbf{S n}$ group, with a biovolume of $38.25 \mathrm{~mm}^{3} . \mathrm{L}^{-1}$, indicating a large quantity of the species Cylindrospermopsis raciborskii. Other groups that also stood out were the $\mathbf{B}$ in $\mathrm{BQ}$, represented by the diatom Synedra $s p$., whose contribution was $14 \%$ of the total biovolume. Closterium sp., A chlorophyce belonging to the P-functional group, had a $10 \%$ share of the biovolume in GAR (Figure 6). The other groups were not representative. The density of cyanobacteria was very high in the five reservoirs: GAR $\left(>11.10^{6} \mathrm{cel} / \mathrm{mL}\right)$; PT $\left(>2.35 .10^{6} \mathrm{cel} / \mathrm{mL}\right)$; ARG $\left(>1.42 .10^{6} \mathrm{cel} / \mathrm{mL}\right)$; IT $\left(>3.97 .10^{3} \mathrm{cel} / \mathrm{mL}\right)$ and BQ $\left(>1.27 .10^{6} \mathrm{cel} / \mathrm{mL}\right)$. The microcystin concentration was at least $3.1 \mu . \mathrm{L}-1$ (BQ), and a maximum of $3.4 \mu . \mathrm{L}-1$ (PT), being higher in ARG, GAR and PT.

\section{Discussion}

Semi-arid regions are characterized by prolonged drought and a short period of rainfall, which, together with multiple uses, leads to a reduction in water volume and an increase in water residence time, particularly in reservoirs, due to the need to maintain a minimum flow to guarantee uses in periods of extreme scarcity. Studies have shown that low water levels in aquatic ecosystems

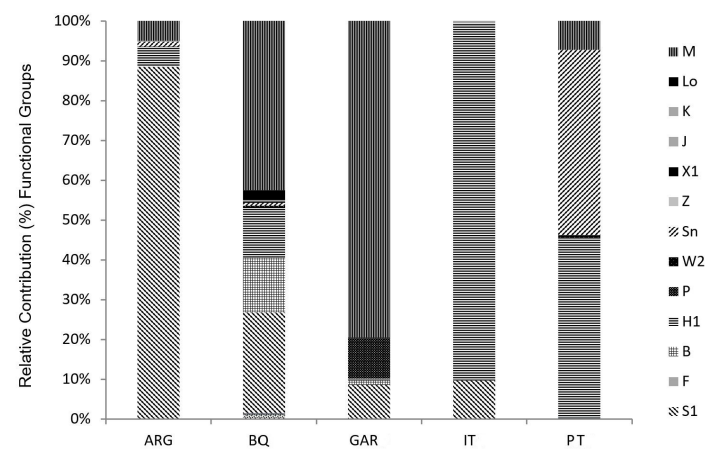

Figure 6. Relative contribution (\%) of the main functional groups in each reservoir in July and August 2015. $\mathrm{ARG}=$ Armando Ribeiro Gonçalves; $\mathrm{BQ}=$ Boqueirão; $\mathrm{GAR}=$ Gargalheiras; $\mathrm{IT}=$ Itans $; \mathrm{PT}=$ Passagem das Traíras. 
of these regions are often associated with high levels of nutrients and organic matter, evolving to increase algal biomass and consequently turbidity (Naselli-Flores, 2003; Bouvy et al., 2003; Costa et al., 2006a, 2009). Thus, the reduction of the amount of rainfall and the use of water influence the availability of light in the system (Xiao et al., 2011), which in turn, as a cascade effect, modifies its trophic state, interfering strongly in the dynamics of phytoplankton (Barbosa et al., 2012). This is because, light availability, nutrients and system mixing regime are determinant for phytoplankton growth and distribution (Reynolds, 2006). On the other hand, the reduction of water level in reservoirs, for example, favors the increase of water residence time, leading to the dominance of strategically and potentially toxic cyanobacteria (Romo et al., 2013), which culminates in the aggravation of eutrophication and consequent loss of water quality (Padisak and Reynolds, 1998). The definition of this scenario in regions subject to the periodic rain scarcity regime, as in the case of the semi-arid region, is of extreme importance for the understanding of the biotic and abiotic processes regulating uhe system, which are essential for predicting cyanobacterial bloom events in water supplies and establishment of prevention and mitigation mechanisms.

Since 2012 the state of Rio Grande do Norte (Brazil) faces one of the most severe droughts ever recorded, severely affecting the local population. The volumes of the reservoirs are drastically reduced, and some have collapse, probably due to the natural and periodic oscillation of regional climate phenomena intensified by El Niño.

The water transparency and volume of the reservoirs ( $>90 \%$ reduction) reported in this study are much lower than those reported by other studies in the same region during less severe periods of water scarcity $(>10<60 \%$ reduction). High levels of total phosphorus and biomass of potentially toxic cyanobacteria were also found. In this condition of drastic reduction of water volume and high turbidity, our results evidenced the permanence and high eutrophic state and the dominance of cyanobacteria in the five reservoirs studied, reinforcing the results obtained in other studies carried out in the same reservoirs (Fonseca et al., 2015; Vieira et al., 2015; Panosso et al., 2007; Eskinazi Sant'Anna et al., 2013; Costa et al., 2009). In the same way, this same scenario is configured in studies carried out in other reservoirs located in the same basin (Freitas et al., 2011; Bezerra, 2011; Medeiros et al., 2015). These results show a strong relationship between the limnetic conditions generated by extreme drought and the loss of water quality and phytoplankton composition. The potential of this relationship is clearly evidenced by the increase in the total biovolume of the phytoplankton, which was at least $89 \%$ and a maximum of $543 \%$ in relation to the values found by other studies carried out in the same reservoirs even under extreme dry conditions. Likewise, the increase in density of cyanobacteria was extremely significant with a minimum of $63 \%$ and a maximum of $471 \%$ (Table 1). In relation to total phosphorus (PT) levels, the five reservoirs analyzed presented extremely high concentrations. In ARG we detected values lower than those found by Vieira et al. (2015), when it presented volume reduction of only $12 \%$, and higher than the value observed by Costa et al. (2009), when the reservoir was $100 \%$ full.

The results show an increase in total phosphorus concentrations based on previous studies. Brazilian legislation regulates the limit of $30 \mu \mathrm{g} . \mathrm{L}^{-1}$ of phosphorus for water intended for human consumption (Brasil, 2005), evidencing the extrapolation of this limit in all reservoirs studied. Values above the recommended limit are also found in other studies of the Brazilian semi-arid region (Huszar et al., 2000; Bouvy et al., 2000). The dominance of cyanobacteria is directly linked to high concentrations of nutrients, mainly phosphorus (Padisák and Reynolds, 1998).

The five reservoirs investigated in this study did not present contamination by heavy metals in the water, but the sediment was contaminated by Chromium and Niquel. The concentration of Bario detected in the water of the reservoirs is within the limits permitted by Brazilian legislation. In the sediment, the limits permitted by Brazilian legislation (Brasil, 2004) for Cromo metal, the acceptable level 2 limit is up to $90 \mathrm{mg} \cdot \mathrm{Kg}^{-1}$, which was exceeded in all dams, with the exception of ARG which showed $88.4 \mathrm{mg} . \mathrm{Kg}^{-1}$. Niquel has a recommended level 2 limit of $35.9 \mathrm{mg} . \mathrm{Kg}^{-1}$ that was also exceeded in all reservoirs. Local studies show high concentrations of heavy metals in several water bodies in the state of Rio Grande do Norte (Sindern et al., 2007), as well as levels of some of these metals found in soil intended for fruit production activities in the Piancó-Piranhas-Açu basin (Morais et al., 2015). Eskinazi-Sant'Anna et al. (2006) found levels of lead, Niquel, Zinco, Manganes, Cadmio and Iron iron above the value allowed by Brazilian legislation in the water of these same reservoirs. The authors warn of the hazards of these metals in water used for human consumption, since these elements are absorbed by the body and can be associated with structures such as proteins and nucleic acids, changing their functionalities. Contamination of water by heavy metals is increasingly an environmental concern because of a lack of degradability, leading to bioaccumulation and magnification in the aquatic biota. The chemical action of metals associated with other disturbances in the system can also cause mortality of organisms at different levels of the aquatic chain.

The drastic reduction of water volume has potentiated the proliferation of cyanobacteria within the phytoplankton community. ARG maintained blooms of Planktothrix agradhii and Cylindrospermopsis raciborskii, already reported by Costa et al. (2009) and Fonseca et al. (2015). Blooms of Sphaerocavum brasiliense and Planktothrix isothrix in BQ and GAR were not found by Costa et al. (2009) and Fonseca et al. (2015), but Medeiros et al. (2015) showed blooms of these species in other semiarid reservoirs in the same period of intense drought. During drought periods the diversity of cyanobacterial species is relatively low, but the cell density is extremely high. Arfi (2005) discusses about this relationship and shows that algal biomass is increased when the reservoir level is low and this algal 
density is benefited by nutrient resuspension and thermal circulation. According to him, larger algal biomass occurs when reservoir levels are low. Rain raises the level of aquatic systems, reducing light availability and algal biomass, generating changes in the composition of different algal associations in tropical systems (Chellappa et al., 2008; Dantas et al., 2008).

The total biomass of phytoplankton is higher in all reservoirs compared to values found by Costa et al. (2009) and Vieira et al. (2015), with the exception of PT. ARG shows an increase ratio of $442 \%$, while in BQ it is $540 \%$; GAR of $530 \%$ and IT about $90 \%$ (Table 1 ). The density of cyanobacteria detected in this study was very high in relation to the values found by Costa et al. (2009) and Fonseca et al. (2015), whose density was less than $500.000 \mathrm{cel} . \mathrm{ml}^{-1}$. The values exceeded acceptable levels for drinking water of 20,000 cel. $\mathrm{ml}^{-1}$, in accordance with Brazilian legislation (Brasil, 2011). The registered microcystin levels exceeded the value of $1.0 \mu \mathrm{g}$. $\mathrm{L}^{-1}$, the maximum limit established for domestic water supplies, in accordance with Brazilian legislation. Concentrations up to $1 \mu \mathrm{g} . \mathrm{L}^{-1}$ of microcystin were recently observed by Fonseca et al. (2015) in ARG, PT, IT and GAR in July 2011 when these reservoirs had the smallest reduction in volume compared to our results. It is important to mention that other toxins such as saxitoxins and cylindrospermopsins may also be present in water, increasing the risk to human health and aquatic biota.

Our results show that the extreme drought conditions, under which the reservoirs were inserted, influenced both phytoplankton composition and water quality, but not the increase in microcystin concentration. Tropical shallow lakes were studied in extreme events in Rio Grande do Norte (Castro et al., 2011), reinforcing the fact that cyanobacteria dominate, high trophic levels and high values of algal biomass in this type of environment. Other studies in the same region report the change in the phytoplankton dynamics and nutrients in the same environments of this study (Costa et al., 2009; Dantas et al., 2012; Vieira et al., 2015). The data obtained expose a fragility of these environments to anthropogenic activities, typical of semi-arid shallow lakes as reported by Fragoso Júnior et al. (2010) in studies of reservoirs in the Brazilian Northeast.

Cyanobacterial composition was common in the reservoirs. In PT, there was predominance of $C$. Raciborskii (group Sn), which are typical of warm and mixed environments. Planktothrix agardhii (group S1) predominated in Armando Ribeiro, as also reported by Vieira et al. (2015), and are also resistant to high turbidity environments (Padisák and Reynolds, 1998). Colonial species S. brasiliense and Microcystis aeruginos a present in almost all environments were favored by low volume, increased availability of phosphorus and low luminosity as found in Medeiros et al. (2015). Although M. aeruginosa did not appear in the same proportion of $S$. brasiliense, both represented GAR and present ecological similarities, since they belong to group $\mathbf{M}$ according to Reynolds et al. (2002). Microcystis aeruginosa is often reported in studies of Brazilian semi-arid reservoirs as one of the most common species in these environments (Dantas et al., 2008; Moura et al., 2011). Aphanocapsa delicatissima was expressively dominant composing bloom in Boqueirão, which because it is a species of shallow habitat and rich in nutrients as the environment in question, belongs to the group K (Reynolds et al., 2002). In GAR the highest bloom was of Planktolyngbya spp., a non-fixating species of atmospheric nitrogen (Dolman et al., 2012). According to the classification of the functional groups Aphanocapsa and Microcystis are taxa characteristic of waters enriched with nutrients, tolerant to high radiation and sensitive to discharges and low total light Reynolds et al. (2002). For Bicudo and Menezes (2006) these species together are characteristic of lakes and eutrophic environments.

The low volume dams and their direct relationship with the high density of cyanobacteria, as Arfi (2005) states, is directly related to the studied environments. The high values of cyanobacteria density were also linked with the high availability of nutrients and reported by Huszar et al. (2000) in eight tropical lakes located in different areas of Brazil, including reservoirs located in the semi-arid. The high turbidity of the reservoirs is one of the factors that constitute them as shallow tropical lakes and is correlated with the presence of species of the functional group S1 typical of turbid and mixed environments.

According to the classification of Reynolds et al. (2002) and updated by Padisák et al. (2009), the groups that prevailed were $\mathbf{S} 1$ representing mixed turbid environments in Armando Ribeiro Gonçalves, $\mathbf{M}$ from eutrophic to hypereutrophic environments, which characterize Gargalheiras, H1 from eutrophic environments with stratification, shallow lakes and low nitrogen level, which is the case of Passagem of the Traíras and Itans. The $\mathbf{S n}$ group of warm and mixed environments mainly characterized of Passagem of the Traíras, while the codon $\mathbf{B}$ of environments of small size to medium, mesotrophic and with species susceptible to stratification and $\mathbf{P}$ of shallow environments with $2 \mathrm{~m}$ to $3 \mathrm{~m}$ of depth high levels of trophic state, Which is the case of Gargalheiras. Vieira et al. (2015) also found functional groups $\mathbf{S 1}$ and $\mathbf{H 1}$ in ARG in July and August of 2011. Costa et al. (2009) showed that phytoplankton was represented basically by $\mathbf{M}$ in the rainy season and, like this work, S1 and Sn in drought, with alternation of species of association H, H1, S1, K and Lo. The main representatives of these groups in the reservoirs were potentially toxic species such as Planktothrix agradhii (S1), Microcystis aeruginosa (M), Anabaena planktonica and Anabaena spp. (H1), Cylindrospermopsis raciborskii (Sn) and other species.

In summary, our results suggest and reaffirm that the severe drought conditions in the semi-arid region, which drastically reduces the volume of water in the reservoirs, alter the light and phosphorus conditions of the system, which are determinant factors to increase the eutrophic condition and consequently the dominance of species of cyanobacteria. Our study shows that the extreme reduction of water volume has increased the cyanobacterial toxic blooms, which is permanently characterized in these reservoirs, in comparison with other studies carried out under conditions of lower water reduction. High concentrations 
of microcystins in water found in this study also reveals an impairment in the decrease of the water quality of reservoirs used for human consumption.

\section{Acknowledgements}

I would like to extend my sincerest thanks to Mr. Edson Santana for field assistance. And I am especially grateful to the Brazilian Coordination for the Improvement of Higher Education Personnel (CAPES) for financing this project and providing the basis for my master's research project.

\section{References}

AMERICAN PUBLIC HEALTH ASSOCIATION -APHA, 2000. Standard methods for the examination of water and wastewater. Washington: APHA.

ARFI, R., 2003. The effects of climate and hydrology on the trophic status of Sélingué Reservoir, Mali, West Africa. Lakes and Reservoirs: Research and Management, vol. 8, no. 3-4, pp. 247-257. http://dx.doi.org/10.1111/j.1440-1770.2003.00223.x.

ARFI, R., 2005. Seasonal ecological changes and water level variations in the Sélingué Reservoir (Mali, West Africa). Physics and Chemistry of the Earth, vol. 30, no. 6-7, pp. 432-441. http:// dx.doi.org/10.1016/j.pce.2005.06.010.

BARBOSA, J.E.D.L., MEDEIROS, E.S.F., BRASIL, J., CORDEIRO, R.D.S., CRISPIM, M.C.B. and SILVA, G.H.G.D., 2012. Aquatic systems in semi-arid Brazil: limnology and management. Acta Limnologica Brasiliensia, vol. 24, no. 1, pp. 103-118. http://dx.doi.org/10.1590/S2179-975X2012005000030.

BEZERRA, A.F.M., 2011. Balanço de massa de fósforo e a eutrofização em reservatórios do semiárido do Rio Grande do Norte, Brasil. Natal: Universidade Federal do Rio Grande do Norte, 88 p. Tese de Doutorado em Engenharia Sanitária.

BICUDO, C.E.M. and MENEZES, M., 2006. Gêneros de algas de águas continentais do Brasil. São Carlos: Rima.

BITTENCOURT-OLIVEIRA, M.C., SANTOS, D.M.S. and MOURA, N.A., 2010. Toxic cyanobacteria in reservoirs in northeastern Brazil: detection using a molecular method. Brazilian Journal of Biology $=$ Revista Brasileira de Biologia, vol. 70, no. 4, pp. 1005-1010. http://dx.doi.org/10.1590/S151969842010000500012. PMid:21180905.

BOUVY, M., FALCÃO, D., MARINHO, M., PAGANO, M. and MOURA, A., 2000. Occurrence of Cylindrospermopsis (Cyanobacteria) in 39 Brazilian tropical reservoirs during the 1998 drought. Aquatic Microbial Ecology, vol. 23, no. 1, pp. 13-27. http://dx.doi.org/10.3354/ame023013.

BOUVY, M., NASCIMENTO, S.M., MOLICA, R.J.R., FERREIRA, A., HUSZAR, V. and AZEVEDO, S.M.F.O., 2003. Limnological features in Tapacurá reservoir (northeast Brasil) during a severe drought. Hydrobiologia, vol. 493, no. 1-3, pp. 115-130. http://dx.doi.org/10.1023/A:1025405817350.

BRAGA, G.G., BECKER, V., OLIVEIRA, J.N.P., MENDONÇA JUNIOR, J.R., BEZERRA, A.F.M., TORRES, L.M., GALVÃO, Â.M.F. and MATTOS, A., 2015. Influence of extended drought on water quality in tropical reservoirs in a semiarid region. Acta Limnologica Brasiliensia, vol. 27, no. 1, pp. 15-23. http://dx.doi. org/10.1590/S2179-975X2214.
BRASIL. Conselho Nacional de Meio Ambiente - CONAMA, 2004. Resolução $n^{\circ} 344$, de 25 de março de 2004. Estabelece as diretrizes gerais e os procedimentos mínimos para a avaliação do material a ser dragado em águas jurisdicionais brasileiras, e dá outras providências. Diário Oficial da República Federativa do Brasil, Brasília, 7 maio.

BRASIL. Conselho Nacional de Meio Ambiente - CONAMA, 2005. Resolução $n^{\circ} 357$, de 15 de março de 2005. Diário Oficial da República Federativa do Brasil, Brasília, 18 mar. 27 p.

BRASIL, 2011. Portaria n ${ }^{\circ} 2.914$, de 12 de dezembro de 2011. Diário Oficial da República Federativa do Brasil, Brasília, 4 jan. 8 p.

BURFORD, M.A. and O'DONOHUE, M.J., 2006. A comparison of phytoplankton community assemblages in artificially and naturally mixed subtropical water reservoirs. Freshwater Biology, vol. 51, no. 5, pp. 973-982. http://dx.doi.org/10.1111/j.13652427.2006.01536.x.

CALIJURI, M.C., SANTOS, A.C.A. and JATI, S., 2002. Temporal changes in the phytoplankton community structure in a tropical and eutrophic reservoir (Barra Bonita, SP, Brazil). Journal of Plankton Research, vol. 24, no. 7, pp. 617-634. http://dx.doi. org/10.1093/plankt/24.7.617.

CASTRO, A.P., QUIRINO, B.F., ALLEN, H., WILLIAMSON, L.L., HANDELSMAN, J. and KRÜGER, R.H., 2011. Construction and validation of two metagenomic DNA libraries from Cerrado soil with high clay content. Biotechnology Letters, vol. 33, no. 11, pp. 2169-2175. http://dx.doi.org/10.1007/s10529-011-0693-6. PMid:21748362.

CHELLAPPA, N.T., BORBA, J.M. and ROCHA, O., 2008. Phytoplankton community and physica-chemical characteristics of water in the public reservoir of Cruzeta, RN, Brazil. Brazilian Journal of Biology = Revista Brasileira de Biologia, vol. 68, no. 3, pp. 477-494. http://dx.doi.org/10.1590/S1519-69842008000300004. PMid:18833468.

CHORUS, I. and BARTRAM, J., 1999. Toxic cyanobacteria in water: a guide to the public health consequences, monitoring and management. London: E \& FN Spon. 416 p.

COSTA, I.A., AZEVEDO, S.M.F.O., SENNA, P.A., BERNARDO, R.R., COSTA, S.M. and CHELLAPPA, N.T., 2006a. Occurrence of toxin-producing cyanobacteria blooms in a Brazilian semiarid reservoir. Brazilian Journal of Biology $=$ Revista Brasileira de Biologia, vol. 66, no. 1B, pp. 211-219. http://dx.doi.org/10.1590/ S1519-69842006000200005. PMid:16710515.

COSTA, I.A.S., SANTOS, A.P., SILVA, A.A., MELO, S.G., SANTOS MENDONÇA, J.M., FÁTIMA PANOSSO, R. and ARAÚJO, M.F.F., 2006b. Florações de algas nocivas: ameaça às águas potiguares. Revista FAPERN, vol. 1, no. 4, pp. 14-16.

COSTA, I. A. S., SOUZA CUNHA, S. R., FÁTIMA PANOSSO, R., ARAÚJO, M. F. F., SOUZA MELO, J. L., \& ESKINAZISANT'ANNA, E. M., 2009. Dinâmica de cianobactérias em reservatórios eutróficos do semi-árido do Rio Grande do Norte. Oecologia Brasiliensis, vol. 13, no. 2, pp. 382-401.

COSTA, M.R.A., ATTAYDE, J.L. and BECKER, V., 2016. Effects of water level reduction on the dynamics of phytoplankton functional groups in tropical semi-arid shallow lakes. Hydrobiologia, vol. 778, no. 1, pp. 75-89. http://dx.doi.org/10.1007/s10750-015-2593-6.

CROSSETTI, L.O. and BICUDO, C.E., 2008. Adaptations in phytoplankton life strategies to imposed change in a shallow urban tropical eutrophic reservoir, Garças Reservoir, over 8 
years. Hydrobiologia, vol. 614, no. 1, pp. 91-105. http://dx.doi. org/10.1007/s10750-008-9539-1.

DANTAS, E.W., BITTENCOURT-OLIVEIRA, M.C. and MOURA, A.N., 2012. Dynamics of phytoplankton associations in three reservoirs in northeastern Brazil assessed using Reynolds' theory. Limnologica, vol. 42, no. 1, pp. 72-80. http://dx.doi. org/10.1016/j.limno.2011.09.002.

DANTAS, E.W., MOURA, A.N. and BITTENCOURTOLIVEIRA, M.C., 2011. Cyanobacterial blooms in stratified and destratified eutrophic reservoirs in semi-arid region of Brazil. Anais da Academia Brasileira de Ciências, vol. 83, no. 4, pp. 1327-1338. http://dx.doi.org/10.1590/S0001-37652011000400019. PMid:22146960.

DANTAS, E.W., MOURA, A.N., BITTENCOURT-OLIVEIRA, M.C., ARRUDA-NETO, J.D.T. and CAVALCANTI, A.D.C., 2008. Temporal variation of the phytoplankton community at short sampling intervals in the Mundaú reservoir, Northeastern Brazil. Acta Botanica Brasílica, vol. 22, no. 4, pp. 970-982. http:// dx.doi.org/10.1590/S0102-33062008000400008.

DOLMAN, A.M., RUCKER, J., PICK, F.R., FASTNER, J., ROHRLACK, T., MISCHKE, U. and WIEDNER, C., 2012. Cyanobacteria and cyanotoxins: the influence of Nitrogen versus Phosphorus. PLoS One, vol. 7, no. 6, pp. 1-14. http://dx.doi. org/10.1371/journal.pone.0038757. PMid:22719937.

EMPRESA E PESQUISAAGROECUÁRIO DO RIO GRANDE DO NORTE - EMPARN [online], 2016 [viewed 18 June 2016]. Available from: http://www.emparn.rn.gov.br

ESKINAZI-SANT'ANNA, E.M., MENEZES, R., COSTA, I.S., ARAÚJO, M., PANOSSO, R. and ATTAYDE, J.L., 2013. Zooplankton assemblages in eutrophic reservoirs of the Brazilian semi-arid. Brazilian Journal of Biology $=$ Revista Brasileira de Biologia, vol. 73, no. 1, pp. 37-52. PMid:23644787.

ESKINAZI-SANT’ANNA, E.M., PANOSSO, R.F., ATTAYDE, J.L., COSTA, I.S., ARAUJO, M., SANTOS, C.M. and MELO, J.L.S., 2006. Águas potiguares: oásis ameaçados. Ciência Hoje, vol. 231, pp. 1-5.

FONSECA, B.M. and BICUDO, C.E.M., 2008. Phytoplankton seasonal variation in a shallow stratified eutrophic reservoir (Garças Pond, Brazil). Hydrobiologia, vol. 600, no. 1, pp. 267-282. http:// dx.doi.org/10.1007/s10750-007-9240-9.

FONSECA, J.R., VIEIRA, P.C.S., KUJBIDA, P. and COSTA, I.A.S.D., 2015. Cyanobacterial occurrence and detection of microcystins and saxitoxins in reservoirs of the Brazilian semiarid. Acta Limnologica Brasiliensia, vol. 27, no. 1, pp. 78-92. http://dx.doi.org/10.1590/S2179-975X2814.

FRAGOSO JÚNIOR, C., MARQUES, D., COLLISCHONN, W. and VAN NES, E., 2010. Modelagem ecológica como ferramenta auxiliar para restauração de lagos rasos tropicais e subtropicais. Revista Brasileira de Recursos Hídricos, vol. 15, no. 2, pp. 15-25. http://dx.doi.org/10.21168/rbrh.v15n2.p15-25.

FREITAS, F.R.S., RIGHETTO, A.M. and ATTAYDE, J.L., 2011. Cargas de fósforo total e material em suspensão em um reservatório do semi-árido brasileiro. Oecologia Australis, vol. 15, no. 3, pp. 655. http://dx.doi.org/10.4257/oeco.2011.1503.16.

HILlEBRAND, H., DÜRSELEN, C.D., KIRSCHTEL, D., POLLINGHER, U. and ZOHARY, T., 1999. Biovolume calculation for pelagic and benthic microalgae. Journal of Phycology, vol. 35, no. 2, pp. 403-424. http://dx.doi.org/10.1046/j.15298817.1999.3520403.x.
HUSZAR, V.L.M., SILVA, L.H.S., MARINHO, M., DOMINGOS, P. and SANT'ANNA, C.L., 2000. Cyanoprokaryote assemblages in eight productive tropical Brazilian waters. In: C.S. REYNOLDS, M. DOKULIL and J. PADISÁK, eds. The trophic spectrum revisited. Netherlands: Springer, pp. 67-77. http://dx.doi.org/10.1007/97894-017-3488-2_6.

KOMÁREK, J. and ANAGNOSTIDIS, K., 2000. Cyanoprokaryota-1. Teil: Chroococcales. Berlin: Spektrum Akademischer Verlag Heidelberg.

KOMÁREK, J. and ANAGNOSTIDIS, K., 2005. Cyanoprokariota, 2: Oscillatoriales. In: B. BÜDEL, L. KRIENITZ, G. GÄRTNER and M. SCHAGERL, eds. Süßwasserflora von Mitteleuropa. München: Elsevier GmbH, vol. 19, no. 2. 758 p.

KOMÁREK, J. and JANKOVSKÁ, V., 2001. Review of the green algal genus Pediastrum: implication for pollenanalytical research. Bibliotheca Phycologica, vol. 108, pp. 1-127.

LAKE, P.S., 2003. Ecological effects of perturbation by drought in flowing waters. Freshwater Biology, vol. 48, no. 7, pp. 1161-1172. http://dx.doi.org/10.1046/j.1365-2427.2003.01086.x.

LUND, J.W.G., KIPLING, C. and LECREN, E.D., 1958. The inverted microscope method of estimating algal number and the statistical basis of estimating by counting. Hydrobiologia, vol. 11, no. 2, pp. 143-170. http://dx.doi.org/10.1007/BF00007865.

MATTEUCCI, S.D. and COLMA, A., 1982. Metodología para el estudio de la vegetación. Washington: Secretaría General de la OEA, Programa Regional de Desarrollo Científico y Tecnológico.

MEDEIROS, L.C., MATTOS, A., LÜRLING, M. and BECKER, V., 2015. Is the future blue-green or brown? The effects of extreme events on phytoplankton dynamics in a semi-arid man-made lake. Aquatic Ecology, vol. 49, no. 3, pp. 293-307. http://dx.doi. org/10.1007/s10452-015-9524-5.

MORAIS, E.R.C., MAIA, C.E., GAUDÊNCIO, H.R.S.C. and SOUSA, D.M.M., 2015. Indicadores da qualidade química do solo em áreas cultivadas com mamoeiro irrigado. Revista Brasileira de Engenharia Agrícola e Ambiental, vol. 19, no. 6, pp. 587-591. http://dx.doi.org/10.1590/1807-1929/agriambi.v19n6p587-591.

MOURA, A.N., DANTAS, E.W., OLIVEIRA, H.S.B. and BITTENCOURT-OLIVEIRA, M.C., 2011. Vertical and temporal dynamics of cyanobacteria in the Carpina potable water reservoir in northeastern Brazil. Brazilian Journal of Biology = Revista Brasileira de Biologia, vol. 71, no. 2, pp. 1-9. http://dx.doi. org/10.1590/S1519-69842011000300015. PMid:21755163.

NASELLI-FLORES, L., 2003. Man-made lakes in Mediterranean semi-arid climate: the strange case of Dr. Deep Lake and Mr. Shallow Lake. Hydrobiologia, vol. 506, no. 1-3, pp. 13-21. http:// dx.doi.org/10.1023/B:HYDR.0000008550.34409.06.

PADISÁK, J. and REYNOLDS, C.S., 1998. Selection of phytoplankton associations in Lake Balaton, Hungary, in response to eutrophication and restoration measures, with special reference to the cyanoprokaryotes. Hydrobiologia, vol. 384, no. 1, pp. 4153. http://dx.doi.org/10.1023/A:1003255529403.

PÁDISAK, J., CROSSETTI, L.O. and NASELLI-FLORES, L., 2009. Use and misuse in the application of the phytoplankton functional classification: a critical review with updates. Hydrobiologia, vol. 621, no. 1, pp. 1-19. http://dx.doi.org/10.1007/ s10750-008-9645-0.

PANOSSO, R., COSTA, I.A.S., SOUZA, N.R., ATTAYDE, J.L., CUNHA, S.R.S. and GOMES, F.C.F., 2007. Cianobactérias e Cianotoxinas em reservatórios do Estado do Rio Grande do 
Norte e o potencial controle das florações pela tilápia do nilo (Oreochromis niloticus). Oecologia Brasiliensis, vol. 11, no. 3, pp. 433-449. http://dx.doi.org/10.4257/oeco.2007.1103.12.

PINTO, T.S. and BECKER, V., 2014. Diel dynamic of phytoplankton functional groups in a tropical water supply, Extremoz Lake, northeastern Brazil. Acta Limnologica Brasiliensia, vol. 26, no. 4, pp. 356-366. http://dx.doi.org/10.1590/S2179-975X2014000400004.

REYNOLDS, C.S., 2006. The ecology of phytoplankton. Cambridge: Cambridge University Press. http://dx.doi.org/10.1017/ CBO9780511542145.

REYNOLDS, C.S., HUSZAR, V., KRUK, C., NASELLI-FLORES, L. and MELO, S., 2002. Towards a functional classification of the freshwater phytoplankton. Journal of Plankton Research, vol. 24, no. 5, pp. 417-428. http://dx.doi.org/10.1093/plankt/24.5.417.

ROMO, S., SORIA, J., FERNÁNDEZ, F., OUAHID, Y. and BARÓN-SOLÁ, Á., 2013. Water residence time and the dynamics of toxic cyanobacteria. Freshwater Biology, vol. 58, no. 3, pp. 513-522. http://dx.doi.org/10.1111/j.1365-2427.2012.02734.x.

ROUND, F., 1971. E., 1971. The taxonomy of the Chlorophyta. II. British Phycological Journal, vol. 6, no. 2, pp. 235-264. http:// dx.doi.org/10.1080/00071617100650261.

SIMONSEN, R., 1979. The diantom system: ideas on phylogeny. Baccilaria, vol. 2, pp. 9-71.

SINDERN, S., LIMA, R.F.S., SCHWARZBAUER, J. and PETTA, R.A., 2007. Anthropogenic heavy metal signatures for the fast growing urban area of Natal (NE-Brazil). Environmental Geology, vol. 52, no. 4, pp. 731-737. http://dx.doi.org/10.1007/ s00254-006-0510-z.

SOARES, M.C.S., MARINHO, M.M., AZEVEDO, S.M.O.F., BRANCO, C.W.C. and HUSZAR, V.L.M., 2012. Eutrophication and retention time affecting spatial heterogeneity in a tropical reservoir. Limnologica, vol. 42, no. 3, pp. 197-203. http://dx.doi. org/10.1016/j.limno.2011.11.002.

SOARES, R.M., 2009. Toxicologia de cianotoxinas: microcistinas as estrelas do tema. Oecologia Brasiliensis, vol. 13, no. 2, pp. 259-271.

ÜTERMOHL, H., 1958. Zur vervollkommnung der quantitativen phytoplankton-methodik. Mitteilungen der Internationalen Vereinigung für theoretische und angewandte Limnologie, vol. 9, pp. 1-38.

VALDERRAMA, J.C., 1981. The simultaneous analysis of total and phosphorus in natural waters. Marine Chemistry, vol. 10, no. 2, pp. 109-122. http://dx.doi.org/10.1016/0304-4203(81)90027-X.

VAN APELDOORN, M.E., VAN EGMOND, H.P., SPEIJERS, G.J. and BAKKER, G.J., 2007. Toxins of cyanobacteria. Molecular Nutrition \& Food Research, vol. 51, no. 1, pp. 7-60. http://dx.doi. org/10.1002/mnfr.200600185. PMid:17195276.

VASCONCELOS, J.F., BARBOSA, J.E.L., DINIZ, C.R. and CEBALLOS, B.S.O., 2011. Cianobactérias em reservatórios do Estado da Paraíba: ocorrência, toxicidade e fatores reguladores. Boletim da Associação Brasileira de Limnologia, vol. 39, no. 2, pp. 1-20.

VIEIRA, P.C.S., CARDOSO, M.M.L. and COSTA, I.A.S., 2015. Vertical and temporal dynamics of phytoplanktonic associations and the application of index assembly in tropical semi-arid eutrophic reservoir, northeastern Brazil. Acta Limnologica Brasiliensia, vol. 27, no. 1, pp. 130-144. http://dx.doi.org/10.1590/S2179-975X2614.

XIAO, L.J., WANG, T., HU, R., HAN, B.P., WANG, S., QIAN, $\mathrm{X}$. and PADISÁK, J., 2011. Succession of phytoplankton functional groups regulated by monsoonal hydrology in a large canyonshaped reservoir. Water Research, vol. 45, no. 16, pp. 5099-5109. http://dx.doi.org/10.1016/j.watres.2011.07.012. PMid:21831406. 